\title{
Pulmonary malakoplakia: a case report and review of the literature
}

\author{
Deniz KÖKSAL ${ }^{1}$ \\ Ayşenaz ÖZCAN ${ }^{2}$ \\ Funda DEMIRAĞ ${ }^{3}$ \\ Beril AKMAN ${ }^{4}$ \\ Leyla Nesrin $\mathrm{ACAR}^{5}$ \\ Erkmen GÜLHAN ${ }^{5}$ \\ Özlem ÖZMEN ${ }^{6}$
}

${ }^{1}$ Department of Chest Diseases, Faculty of Medicine, Hacettepe University, Ankara, Turkey

${ }^{1}$ Hacettepe Üniversitesi Tıp Fakültesi, Göğüs Hastalıkları Anabilim Dalı, Ankara, Türkiye

2 Department of Chest Diseases, Ankara Ataturk Chest Diseases and Chest Surgery Training and Research Hospital, Ankara, Turkey

2 Ankara Atatürk Göğüs Hastalıkları ve Gögüus Cerrahisi Eğitim ve Araştırma Hastanesi, Göğüs Hastalıkları Kliniği, Ankara, Türkiye

${ }^{3}$ Department of Patology, Ankara Ataturk Chest Diseases and Chest Surgery Training and Research Hospital, Ankara, Turkey

3 Ankara Atatürk Göğüs Hastalıkları ve Gögüs Cerrahisi Ĕ̆itim ve Araştırma Hastanesi, Patoloji Kliniği, Ankara, Türkiye

${ }^{4}$ Department of Nephrology, Ankara Guven Hospital, Ankara, Turkey

${ }^{4}$ Ankara Güven Hastanesi, Nefroloji Bölümü, Ankara, Türkiye

${ }^{5}$ Department of Chest Surgery, Ankara Ataturk Chest Diseases and Chest Surgery Training and Research Hospital, Ankara, Turkey

${ }^{5}$ Ankara Atatürk Göğüs Hastalıkları ve Göğüs Cerrahisi Eğitim ve Araştırma Hastanesi, Göğüs Cerrahisi Kliniği, Ankara, Türkiye

${ }^{6}$ Department of Nuclear Medicine, Ankara Ataturk Chest Diseases and Chest Surgery Training and Research Hospital, Ankara, Turkey

${ }^{6}$ Ankara Atatürk Göğüs Hastalıkları ve Göğüs Cerrahisi Eğitim ve Araştırma Hastanesi, Nükleer Tıp Bölümü, Ankara, Türkiye

\section{INTRODUCTION}

Malakoplakia is a rare inflammatory condition characterized by the accumulation of aggregates of histiocytes that contain concentrically layered basophilic inclusions called Michaelis-Gutmann bodies. It was first described by Michaelis and Gutmann in 1902 and later by Von Hanseman who named the lesion as "malakoplakia" meaning "soft plaque". It is usually an infectious process associated with a variety of bacterial infections and has been associated with immunocompromised states. Malakoplakia can form tumor-like nodules that clinically simulate malignancy in a variety of organs. It is commonly a disease of urinary tract, but it may involve any organ such as colon, stomach, lung, liver, bone, uterus, and skin (1). The occurrence of malakoplakia in lung is not common and a total of 38 cases have been reported in the current English written literature (2-28). In this paper, we aimed to present a case of pulmonary malakoplakia in a renal transplant recipient and to review the literature.

\section{Yazışma Adresi (Address for Correspondence)}

Dr. Deniz KÖKSAL

Hacettepe Üniversitesi Tıp Fakültesi, Göğüs Hastalıkları Anabilim Dalı, ANKARA - TURKEY

e-mail: deniz_koksal@yahoo.com 


\section{CASE REPORT}

A 47-year-old male patient who had received a cadaveric renal transplant 18 months ago was referred to our clinic for the evaluation of an incidental solitary pulmonary nodule detected on chest radiography during routine follow-up. The patient was a former smoker with a smoking history of 25 pack-years. He was asymptomatic and there was no evidence of infection. He was on immunosupressive regimen that included tacrolimus $6 \mathrm{mg} /$ day, mycophenolate sodium $1440 \mathrm{mg} /$ day and prednisolone $5 \mathrm{mg} /$ day. Physical examination was unremarkable. Routine laboratory analysis including complete blood count, basic metabolic panel, urine analysis were normal apart from a mild elevated creatinine level of $1.5 \mathrm{mg} / \mathrm{dL}$. Anti$\mathrm{HCV}$ was positive. The urine and sputum cultures were all negative for any pathogen. On chest radiography, there was an ill-defined solitary pulmonary nodule, $1.5 \mathrm{~cm}$ in diameter, on the left hemithorax. That nodule was not present on a previous chest radiography obtained 6 months ago. The positron emission tomography with computed tomography (PET/ CT) showed an increased uptake of 18-fluorodeoxyglucose with a maximum standardized uptake value of 9.78 limited to the pulmonary nodule in the superior segment of left lower lobe (Figure 1). The patient was referred to chest surgery clinic for surgical excision with the suspicion of an early stage lung cancer. Since the frozen section was compatible with benign histology, the nodule was removed by wedge resection. As shown in Figure 2A, the histologic examination of the surgical specimens revealed sheets of histiocytes containing abundant eosinophilic cytoplasm and chronic inflammatory infiltrates of plasma cells and lymphocytes. Histiocytes were positive with
CD68 and some histiocytes contained MichaelisGutmann bodies in periodic acid-schiff stain (PAS) (Figure 2). We failed to isolate any microbiological agent. After one and a half year follow-up time, the patient was stable with no dissemination of infection.

\section{DISCUSSION}

Herein we present a renal transplant recipient patient diagnosed as pulmonary malakoplakia after thoracotomy performed for the evaluation of a solitary pulmonary nodule. Malakoplakia is a distinct chronic granulomatous inflammatory disease seen mainly in immunocompromised hosts, caused by a variety of

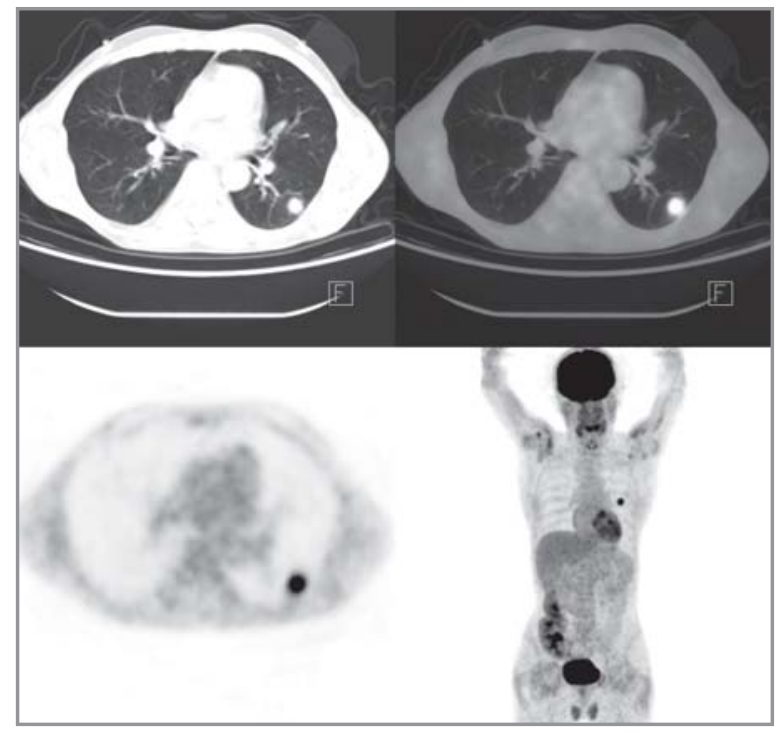

Figure 1. High FDG uptake on the solitary pulmonary nodule located on the superior segment of left lower lobe. Activity is seen on the transplanted kidney in the right lower quadrant of abdomen due to renal excretion of FDG.

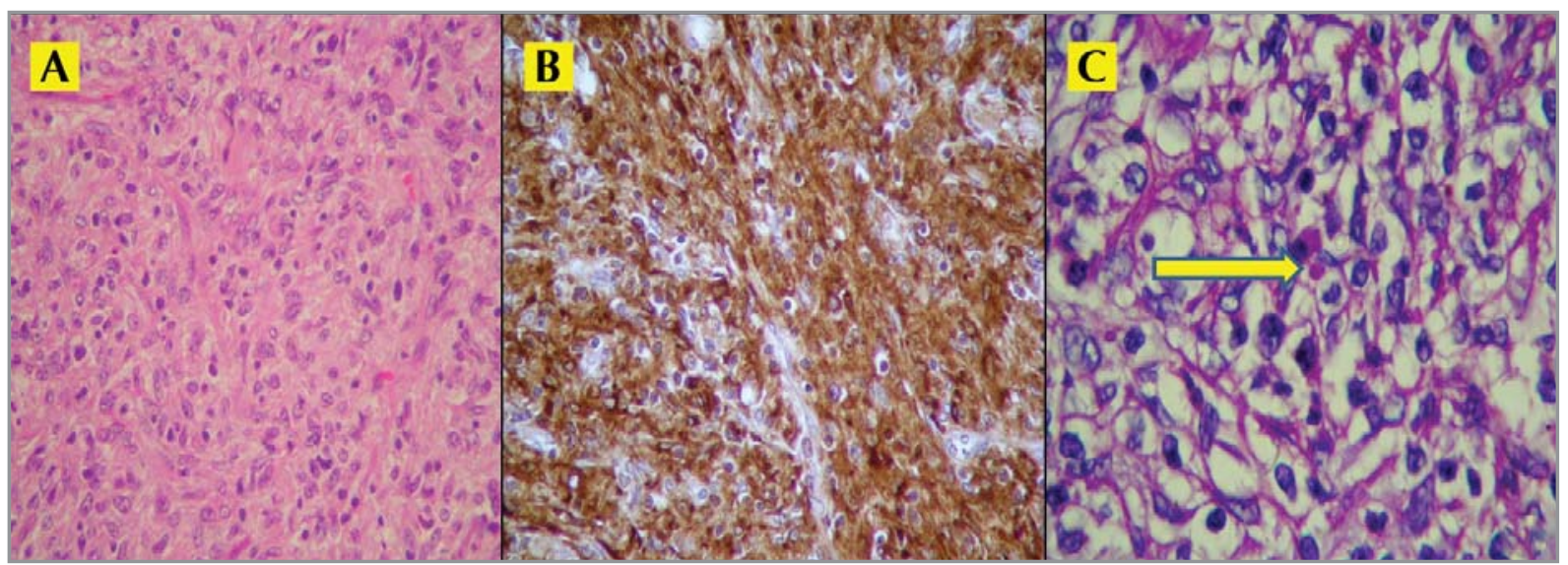

Figure 2. (A) Sheets of eosinophilic histiocytes (HEX400), (B) CD68 positivity in histiocytes (CD68X400), (C) Michaelis-Gutmann bodies in PAS stain (PASX1000). 
infectious agents, mostly bacteria. The pathogenesis of malakoplakia is unknown, but is considered as an abnormal response to bacterial infection mediated by an acquired defect in macrophage function. The macrophages show normal phagocytic activity but manifest abnormal intracellular killing or digestion of bacteria, probably secondary to defective lysosomal degranulation and impaired acidification of phagolysosomes (5). The diagnosis is made by demonstrating certain characteristic histological features such as Von Hansemann histiocyte and Michaelis-Gutmann bodies. The Michaelis-Gutmann bodies are formed by deposition of calcium and iron on residual bacterial glycolipids (2).

Malakoplakia rarely affects the pulmonary system. Most of the malakoplakia cases reported until 1971 have occurred in the genito-urinary tract and has been associated with Escherichia coli infections (29). In 1972, for the first time Gupta et al. was reported the autopsy findings of a pulmonary malakoplakia case. The patient was in a markedly debilitated health status presenting with involvement of lungs and vertebrae mimicking a metastatic carcinoma (2). Subsequently pulmonary malakoplakia cases were reported in individuals with organ transplant recipients, hematologic malignancies, lymphomas, alcohol abuse, acquired immunodeficiency syndrome (AIDS), diabetes mellitus, corticosteroid receivers, and finally immunocompetents $(3,5-8,10$ $13,16,18,23,25-28)$. Table 1 represents the adult pulmonary malakoplakia cases $(n=38$ cases) reported between 1972-2012, in the English written literature (2-28). Most of these cases were associated with an immunocompromised state, mostly AIDS and transplant recipients.

Pulmonary malakoplakia follows a subacute or chronic course with fever and non-specific symptoms. Pulmonary mass lesions, cavitating masses, cavitating pneumonias, and multiple pulmonary nodules are the most common radiological findings. There are also cases involving the pleura and the trachea $(9,13,21,27)$. Our patient was presented with a solitary pulmonary nodule. He was asymptomatic and the nodule was detected on chest radiography during routine follow-up. We think that early diagnosis prevented the progression of disease.

Malakoplakia is associated with certain bacteria such as a gram-positive coccobasilli Rhodococcus equi and gram-negative bacilli $E$. coli (Table 1). Whereas genitourinary malakoplakia is usually associated with long standing urinary tract infection with gram-nega- tive enteric basilli (mostly E. coli), R. equi has been implicated in the majority of cases with pulmonary malakoplakia. Lung lesions are mostly associated with AIDS. Pasteurella multocida was the opportunistic pathogen in a patient with AIDS (23). In the presented patient, we failed to isolate any bacteria. This was not a handicap for us since the single nodule was resected and we do not planned to give any antibiotic therapy.

The differential diagnosis of pulmonary malakoplakia includes pulmonary tuberculosis, primary or metastatic malignancies, and vasculitis such as Wegener's granulomatosis. Our patient had a solitary pulmonary nodule with an increased uptake on PET/CT and he underwent thoracotomy with the suspicion of early stage lung cancer.

The currently avaliable best treatment for malakoplakia is the combination a prolonged antibiotic therapy (quinolones, rifampin, macrolides, tetracyclins or combination of these drugs) using drugs with good penetration into macrophages and surgical resection of the infected tissue (9). Quinolone antibiotic treatment and surgical excision lead to the highest cure rates $(90 \%$ and $81 \%$, respectively). Specific intracellular penetration of quinolone antibiotics is a possible reason for the higher cure rate achieved with these antibiotics (30). The duration of treatment is not well defined. Duration of therapy can be affected by the site, extent of tissue involvement, type of isolated organism and immune status of the patient. Sometimes several months seem necessary for cure. Tapering or discontinuation of immunosupressive therapy whenever possible can also facilitate cure. Bethanechol chloride, a cholinergic agent, that is supposed to enhance macrophage bactericidal activity through raising cytoplasmic cyclic guanosine monophosphate level, has been tried in disseminated malakoplakia, however there is still no convincing evidence of its clinical efficacy (4). In our patient, after complete resection of the pulmonary nodule, there was no concensus about the need for a course of antibiotic therapy that we did not give any further therapy. After one and a half year follow-up time, the patient was stable with no dissemination of infection.

In conclusion, despite being a rare clinical entity, pulmonary malakoplakia should be kept in mind in the etiology of pulmonary nodules in transplant recipients. Its rarity might be due to underdiagnosis. Malakoplakia should be added to the list of unusual infectious disease occurring at unusual sites in immuncompromised hosts. Strong suspicion is required both clinically and histologically to diagnose this condition. 
Table 1. Reported adult pulmonary malakoplakia cases in English written literature

\begin{tabular}{|c|c|c|c|c|}
\hline Reference & $\begin{array}{l}\mathrm{N} \text { of } \\
\text { cases }\end{array}$ & $\begin{array}{l}\text { Type of pulmonary } \\
\text { involvement }\end{array}$ & Risk factors & Infectious agent \\
\hline 1972, Gupta RK (2) & 1 & Bilateral pulmonary masses & $\begin{array}{l}\text { Markedly debilated } \\
\text { health status }\end{array}$ & E. coli, Klebsiella \\
\hline 1980, Colby TV (3) & 2 & $\begin{array}{l}\text { Focal lesions showing some } \\
\text { response to antibiotic therapy }\end{array}$ & $\begin{array}{l}\text { Cardiac transplantation } \\
\text { Hodgkin's disease }\end{array}$ & R. equi \\
\hline 1984, Hodder RV (4) & 1 & Cavitating mass & Renal transplantation & E. coli \\
\hline 1984, Crouch E (6) & 1 & $\begin{array}{l}\text { Bilateral multiple } \\
\text { pulmonary nodules }\end{array}$ & Heavy alcohol abuse & E. coli \\
\hline 1990, Scannell KA (6) & 1 & Cavitating pneumonia & AIDS & R. equi \\
\hline 1990, Schwartz DA (7) & 1 & Cavitating mass & AIDS & R. equi \\
\hline 1993, Liberati F (8) & 1 & Pulmonary mass & AIDS & M. tuberculosis \\
\hline 1994, Mollo JL (9) & 1 & $\begin{array}{l}\text { Trachea involvement } \\
\text { Pneumonia }\end{array}$ & $\begin{array}{c}\text { Low CD4 } \\
\text { lymphocyte count }\end{array}$ & E. coli \\
\hline 1994, Russel GM (10) & 1 & Consolidation & AIDS & R. equi \\
\hline 1994, Kwon KY (11) & 4 & Cavitating mass & AIDS & R. equi \\
\hline $\begin{array}{l}\text { 1994, de } \\
\text { Peralta-Venturina MN (12) }\end{array}$ & 1 & Cavitary pneumonia & AIDS & R. equi \\
\hline 1995, Calore EE (13) & 1 & $\begin{array}{c}\text { Pleuropulmonary } \\
\text { involvement, empyema }\end{array}$ & AIDS & R. equi \\
\hline 1996, Öztürkçügil C (14) & 1 & $\begin{array}{l}\text { Bilateral multiple } \\
\text { pulmonary nodules }\end{array}$ & $\begin{array}{l}\text { No known } \\
\text { immunodeficiency }\end{array}$ & - \\
\hline 1996, Yuoh G (15) & 3 & $\begin{array}{l}\text { Cavitating mass (2) } \\
\text { Nodular lesions (1) }\end{array}$ & AIDS & R. equi \\
\hline 1996, van Hoeven KH (16) & 1 & Cavitating mass & Liver transplantation & R. equi \\
\hline 1997, Sughayer M (17) & 1 & $\begin{array}{l}\text { Bilateral multiple } \\
\text { cavitary lesions }\end{array}$ & AIDS & R. equi \\
\hline 1997, Lambert C (18) & 1 & Giant mass, $10 \mathrm{~cm}$ & Lymphoma & R. equi \\
\hline 1999, Guerrero (19) & 1 & Cavitating pneumonia & AIDS & R. equi \\
\hline 1999, Shin MS (20) & 1 & $\begin{array}{l}\text { Cavitating mass and } \\
\text { multiple nodules }\end{array}$ & AIDS & R. equi \\
\hline $\begin{array}{l}\text { 2000, Caterino-de-Araujo } \\
\text { A (21) }\end{array}$ & 1 & $\begin{array}{l}\text { Pleuropulmonary } \\
\text { involvement }\end{array}$ & AIDS & R. equi \\
\hline 2002, Bastas A (22) & 1 & Pulmonary mass & AIDS & P. multocida \\
\hline 2005, Pang LC (23) & 1 & Consolidation & $\begin{array}{l}\text { Diabetes mellitus } \\
\text { Steroid therapy for asthma }\end{array}$ & $\begin{array}{c}\text { E. coli } \\
\text { (coexistant lymph } \\
\text { node tuberculosis) }\end{array}$ \\
\hline 2006, Kilicgun A (24) & 1 & $\begin{array}{l}\text { Bilateral pulmonary } \\
\text { and pleural nodules }\end{array}$ & Type 2 diabetes mellitus & - \\
\hline 2011, Gupta K (26) & 2 & $\begin{array}{l}\text { Pulmonary mass } \\
\text { Empyema }\end{array}$ & $\begin{array}{l}\text { Immunocompetent with } \\
\text { no identifiable risk factor }\end{array}$ & - \\
\hline 2011, Mandal P (26) & 1 & Pulmonary mass & $\begin{array}{l}\text { Immunocompetent with } \\
\text { no identifiable risk factor }\end{array}$ & - \\
\hline 2012, Behnes CL (27) & 1 & Pleural mass & Stem cell transplantation & R. equi \\
\hline 2012, Mule A (28) & 5 & Pulmonary nodules & $\begin{array}{l}\text { Immunocompetent with } \\
\text { no identifiable risk factor }\end{array}$ & R. equi \\
\hline The present case & 1 & Solitary pulmonary nodule & Renal transplantation & - \\
\hline
\end{tabular}




\section{CONFLICT of INTEREST}

None declared.

\section{REFERENCES}

1. Lack EE. Malakoplakia. In: Connor DH, Chandler FW, Schwartz DA, Manz HJ, Lack EE (eds). Pathology of Infectious Diseases. Vol 2, Stanford, Connecticut: Appleton and Lange, 1997:1647-54.

2. Gupta RK, Schuster RA, Christian WD. Autopsy findings in a unique case of malakoplakia. A cytoimmunohistochemical study of Michaelis Gutmann bodies. Arch Pathol 1972;93:42-8.

3. Colby TV, Hunt S, Pelzmann K, Carrington CB. Malakoplakia of the lung: report of two cases. Respiration 1980;39:295-9.

4. Hodder RV, St-George-Hyslop P, Chalvardjian A, Bear RA, Thomas P. Pulmonary malakoplakia. Thorax 1984;39:70-1.

5. Crouch E, Wright J, White V, Churg A. Malakoplakia mimicking carcinoma metastatic to lung. Am / Surg Pathol 1984;8:151-6.

6. Scannell KA, Portoni MA, Finkle HI, Rice M. Pulmonary malakoplakia and Rhodococcus equi infection in a patient with AIDS. Chest 1990;97:1000-1.

7. Schwartz DA, Ogden PO, Blumberg HM, Honig E. Pulmonary malakoplakia in a patient with the acquired immunodeficiency syndrome. Differential diagnostic considerations. Arch Pathol Lab Med 1990;114:1267-72.

8. Liberati F, Farabi R, Ascani S. Pulmonary malakoplakia in AIDS. AIDS 1993;7:1280-1.

9. Mollo IL, Groussard O, Baldeyrou P, Molsa G, Fournier M, Pariente R. Tracheal malakoplakia. Chest 1994;105:608-10.

10. Russell GM, Mills AE. Pulmonary malakoplakia related to Rhodococus equi occuring in the acquired immunodeficiency syndrome. Med J Aust 1994;160:308-9.

11. Kwon KY, Colby TV. Rhodococcus equi pneumonia and pulmonary malakoplakia in acquired immunodeficiency syndrome. Pathologic features. Arch Pathol Lab Med 1994; 118:744-8

12. De Peralta-Venturina MN, Clubb FJ, Kielhofner MA. Pulmonary malacoplakia associated with Rhodococcus equi infection in a patient with acquired immunodeficiency syndrome. Am J Clin Pathol 1994;102:459-63.

13. Calore EE, Vazquez CR, Perez NM, Cavaliere MJ, Curti R Jr, Campos Salles PS, et al. Empyema with malakoplakic-like lesions by Rhodococcus equi as a presentation of HIV infection. Pathologica 1995;87:525-7.

14. Özkürkçügil C, Düzcan E, Gültekin Y, Gökalp A. A case of renal parenchymal malakoplakia with bilateral pulmonary lesions. Br I Urol 1996:77:159-60.

15. Yuoh G, Hove MG, Wen J, Haque AK. Pulmonary malakoplakia in acquired immunodeficiency syndrome: an ultrastructural study of morphogenesis of Michaelis-Gutmann bodies. Mod Pathol 1996;9:476-83.
16. van Hoeven $\mathrm{KH}$, Dookhan DB, Petersen RO. Cytologic features of pulmonary malakoplakia related to Rhodococcus equi in an immunocompromised host. Diagn Cytopathol 1996; 15:325-8

17. Sughayer M, Ali SZ, Erozan YS, Dunsmore N, Hall GS. Pulmonary malacoplakia associated with Rhodococcus equi infection in an AIDS patient. Report of a case with diagnosis by fine needle aspiration. Acta Cytol 1997;41:507-12.

18. Lambert C, Gansler T, Mansour KA, Schwartzmann SW, Duffell GM, Gal AA. Pulmonary malakoplakia diagnosed by fine needle aspiration. A case report. Acta Cytol 1997;41:1833-8.

19. Guerrero MF, Ramos JM, Renedo G, Gadea I, Alix A. Pulmonary malacoplakia associated with Rhodococcus equi infection in patients with AIDS: case report and review. Clin Infect Dis 1999;28:1334-6.

20. Shin MS, Cooper JAD, Ho KJ. Pulmonary malakoplakia associated with Rhodococcus equi infection in apatient with AIDS. Chest 1999; 115:889-92.

21. Caterino-de-Araujo A, de los Santos-Fortuna E, ZandonáMeleiro MC, Calore EE, Perez Calore NM. Detection of the 20-kDa virulence-associated antigen of Rhodococcus equi in malakoplakia-like lesion in pleural tissue obtained from an AIDS patient. Pathol Res Pract 2000;196:321-7.

22. Bastas A, Markou N, Botsi C, Myrianthefs P, Trigidou R, Poulakis $N$, et al. Malakoplakia of the lung caused by Pasteurella multocida in a patient with AIDS. Scand I Infect Dis 2002;34:536-8.

23. Pang LC. Pulmonary malakoplakia coexistent with tuberculosis of the hilar lymph node mimicking malignancy. Respiration 2005;72:95-100.

24. Kiliçgün A, Turna A, Gürses A. Pulmonary malacoplakia. Acta Chir Belg 2006;106:732-3.

25. Gupta K, Thakur S. Pulmonary malakoplakia: a report of two cases. Indian J Pathol Microbiol 2011;54:133-5.

26. Mandal P, Wallace WA, Skwarski KM. Pulmonary malakoplakia: a rare presentation mimicking extensive stage IV lung cancer. Eur Respir I 2011;38:983-5.

27. Behnes CL, Neumann S, Schweyer S, Radzun HJ. Pleural malakoplakia caused by Rhodococcus equi infection in a patient after stem cell transplantation. Diagn Pathol 2012;23:7:20. doi: 10.1186/1746-1596-7-20.

28. Mulè A, Petrone G, Santoro A, Sanguinetti M, Meacci E, Coli A, et al. Pulmonary malacoplakia at early stage: use of polymerase chain reaction for detection of Rhodococcus equi. Int J Immunopathol Pharmacol 2012;25:703-12.

29. Damjanov I, Katz SM. Malakoplakia. Pathol Annu 1981;16:103-26.

30. Van der Voort HJ, ten Velden JA, Wassenaar RP, Silberbusch J. Malacoplakia. Two case reports and a comparison of treatment modalities based on a literature review. Arch Intern Med 1996;156:577-83. 